\title{
Rumelili Murtazâ Sükûti Divanı’ndaki Elif-nâmeler
}

Nurgül ÖZCAN

\begin{abstract}
APA: Özcan, N. (2019). Rumelili Murtazâ Sükûti Divanı'ndaki Elif-nâmeler. RumeliDE Dil ve
\end{abstract} Edebiyat Araştırmaları Dergisi, (15), 263-273. DOI: 10.2900o/rumelide.580571

\section{$\ddot{\mathbf{O} z}$}

Rumelili Murtazâ Sükûtî, Makedonya sınırları içindeki Köprülü kasabasında yaşamış Sa'dî tarikatına mensup sûfî bir şairdir. Şairin bilinen tek eseri olan divanı Berlin Devlet Kütüphanesi'ndedir. Murtazâ Sükûtî Divanı dinî tasavvufî muhtevalı şiirlerden oluşmaktadır. Edebiyatımızda, değişik konularda yazılan 'elif-nâmeler'e rastlanmaktadır. Elif-nâmelerde farklı konular işlenmekle beraber genellikle dinî-tasavvufî temalar tercih edilmektedir. Elif-nâmeler misra ya da beyit başlarında sırasıyla ya da ters olarak Arap harflerinin sıralanmasıyla oluşturulmaktadır. Klasik Türk Edebiyatı'nda gazel, mesnevi, murabba, muhammes vb. çeşitli nazım şekilleriyle yazılan elifnâmelere rastlamak mümkündür. Akademik çevrelerde elif-nâmelerin şekil mi tür mü olduğu hakkında farklı görüşler bulunmaktadır. Sükûtî Divanı’nda yer alan iki elifnâme de düvâznâme türünde yazılmıştır. Alevi-Bektaşi edebiyatında yaygın olarak örnekleri görülen On İki İmam’ın özelliklerini konu edinen 'düvâz-deh', ‘düvâz-imam' veya 'düvâz-nâme' olarak adlandırılan bir şiir türü bulunmaktadır. Alevi-Bektaşi kökenli şairlerin dışında da bu türde şiirler yazılmıştır. Düvâznâmelere hem Türk Halk Edebiyatı'nda hem de Klasik Türk Edebiyatı'nda rastlamak mümkündür. Murtazâ Sükûtî Divanı'nda toplam otuz altı adet düvâz-nâme bulunmaktadır. Sükûtî, eserinde edebi türler içinde en fazla düvâz-nâme türüne yer vermiştir. Bu çalışmada, elif-nâme ve düvâz-nâme hakkında bilgi verilerek Rumelili Murtazâ Sükûtî Divanı'ndaki elif-nâmeler şekil ve muhteva açısından karşılaştırılarak, tahlil edilecektir.

Anahtar kelimeler: Elif-nâme, Düvâz-nâme, Sükûtî, Tasavvuf Şiiri, On İki İmam

\section{Elif-nâmes in the Divan of Murtazâ Sükûtî}

\begin{abstract}
Murtazâ Sükûtî is a sufi poet who lived in the 19th century. Sükûtî a member of Sâdi sect. He started his education in his village and continued in the city of Köprülü in Macedonia. Then he received Islamic mysticism education. He cited poems on subject of religion and Sufism. He received nickname "Sükûtî". Poets have always produced original and esthetical works while forming their poetry. "elif-nâmes" written in various topics and in the forms inspired by the array of Arabic letters take place in both Divan and Folk Literatures. Religious and Sufi themes are usually included in elifnâmes. It is still controversial that whether elif-nâmes are called a type or a form. Moreover, poems named as ‘düvâz-deh', ‘düvâz-imam' or 'düvâz-nâme’ which tell about twelve imams are commonly included in Alevî-Bektaşî literature. Divan of Sükûtî has many poems warning and providing advice to the reader in terms of religion, Sufism, morals, and being a good person. In this study the poems in the divan of Sükûtî written in the elif-nâme-düvâznâme genre/style have been determined according to their form of poetry and the themes of these poems were analyzed.
\end{abstract} tarihi:16.06.2019; DOI: 10.29000/rumelide.580571] 
Keywords: Elif-nâme, Düvâz-nâme, Sükûtî, tasavvuf poetry, Twelfe İmam.

\title{
1. Murtazâ Sükûtî
}

Murtazâ Sükûtî, günümüzde Makedonya sınırları içinde bulunan Köprülü'de H.1241 (M.1825) yılında doğmuş, hayatının büyük bölümünü burada sürdürmüştür. H.1312 (M.1896) yılında yine Köprülü'de vefat etmiştir.

Tarihin derinliklerinden günümüze uzanan kültür merkezlerinden biri olan Makedonya’nın önde gelen ailelerinden birine mensup olan Sükûtî , tasavvuf kültürüne aşina bir çevrede yetişmiştir. Askerlik için gittiği Prizren'de Sa'diyye tarikatı mensuplarıyla tanışmış, zamanla bu tarikatta şeyhlik mertebesine kadar yükselmiştir. (Özdamar, 1997: 22) Şairin yetiştiği manevi-edebi muhit -bilhassa Köprülü şehriTürk tasavvuf kültüründe müstesna bir yere sahiptir. "XVIII. yüzyllın ilk yarısında şehirde kurulan büyük Halvetî Tekkesi, XX. yüzyılın sonlarına kadar aktif biçimde kullanılmıştır. Tepedelenli Ali Paşa burada Sa'diyye tarikatı adına 1800 yıllarında bir tekke kurmuştur.” (Kiel, 2016: 82) Birçok tarikatın Makedonya'daki merkezi Köprülü'ye yakın bir coğrafyada bulunmaktadır. Bu bölgede Nakşibendi, Halvetî, Rufâî veBektaşîler'in tekkeleri bulunmaktadır. Tekke ve dergâhlar, faaliyet gösterdikleri çevrelerde manevi fonksiyonlarının yanı sıra Türk-İslam kültürünün gelişmesi ve yayılması adına birer eğitim merkezi olarak da ciddi görevler ifa etmekteydiler.

Gençliğinde Köprülü'de aldığı manevi temelin yanında Sa'diyye tarikatındaki seyr ü sülûkunu tamamlayan Murtazâ Sükûtî daha sonra Muhammed Harâbâtî Baba Hazretleri’nin dergâh-ı şerifinde vekâleten post-nişînlik yapmış, Sa'diyye tarikatında önemli hizmetlerde bulunmuştur. Şair, H.1312 (M. 1896) yllında bu dergâhta vefat etmiştir ve yine buraya defnedilmiştir. Daha sonra Selânik demiryolunun dergâhın bulunduğu yere isabet etmesi dolayısıyla Murtazâ Sükûtî Baba'nın kabri İștip kazasının Dorfullu köyüne nakledilmiştir.

\begin{abstract}
“Sükûtî’nin bilinen tek eseri divanıdır. Eserin asl Almanya'da Berlin Staatsbibliothek' tedir. Divan, Kütüphanenin Türkçe El Yazmalar bölümünde (Türkische Hadrschriften) XIII/2, Nu.445-446, Ms.or.quart 1419 olarak kayıtlıdır. Eser 122 varak olup, rik'a hattıyla kaleme alınmıştır. Her sayfada on beş satır bulunmaktadır. Divanun başında ve sonunda kim tarafindan istinsah edildiğine dair her hangi bir bilgi bulunmamaktadır. Eserin istinsah tarihi divanun sonunda 21 Muharrem 1305 olarak kaythdir."(Özcan,2011:23)
\end{abstract}

Şiirlerinin tamamını Türkçe kaleme alan Murtazâ Sükûtî, şiirlerinde sade bir dil, kolay anlaşllır bir üslup kullanmıştır. Sükûtî, divanındaki şiirlerinin çoğunu aruz ölçüsüyle kaleme almıştır. Şairin hece ölçüsüyle yazdığı şiirleri de vardır. Tasavvuf anlayışının yoğun olarak işlendiği Sükûtî Divanı'nda, ağırlıklı olarak; Allah, Hz. Muhammed, Hz. Ali, Ehl-i Beyt ve On İki İmam sevgisi gibi konular işlenmiştir. Zaman zaman rindâne şiirler de yazan Sükûtî, birçok şiirinde edebî derinliği ve estetiği yakalamıştır. Özellikle na’t-ı şeriflerde ve Ehl-i Beyt sevgisinin işlendiği şiirlerde şairin daha coşkulu bir üslup kullandığı görülmektedir. Sükûtî’nin sanatında, her şair gibi yaşadığı coğrafyanın, hizmet ettiği tasavvuf yolunun ve içinde bulunduğu toplumun etkisi göze çarpmaktadır.

Sükûtî Divaninda toplam 470 manzume bulunmaktadır. Bu şiirlerin 464'ü aruz; 6'sı hece ölçüsüyle yazılmıştır. Divanda 392 gazel, 28 rubâî, 28 müfred, 13 murabbâ, 2 muhammes, 3 nazm bulunmaktadır.

\begin{tabular}{|l|l|}
\hline Gazel & 392 \\
\hline Rubâî & 28 \\
\hline Müfred & 28 \\
\hline
\end{tabular}




\begin{tabular}{|l|l|}
\hline Murabbâ & 13 \\
\hline Muhammes & 2 \\
\hline Nazm & 3 \\
\hline
\end{tabular}

Divandaki nazım türlerinin tablosu:

\begin{tabular}{|l|l|}
\hline Düvâz-nâme & 36 \\
\hline Na't & 18 \\
\hline Mersiye & 5 \\
\hline Medhiye & 4 \\
\hline Elif-nâme & 2 \\
\hline Ahvâl-i Enbiyâ & 2 \\
\hline Vücûd-nâme & 2 \\
\hline Ahvâl-i Zamâne & 2 \\
\hline Besmele Şerhi & 1 \\
\hline Pend-nâme & 1 \\
\hline Ramazâniye & 1 \\
\hline
\end{tabular}

Osmanlı Devleti’nin son döneminde, Balkan coğrafyasındaki tasavvuf anlayışını yansıtan Sükûtî Divamı edebi türler açısından oldukça zengindir. Divandaki edebi türlerin büyük bir kısmını 'düvâz-nâmeler' ve 'na’t-ı şerifler' oluşturmaktadır. Sükûtî Divanı'nda bulunan otuz altı düvâz-nâmenin iki tanesi aynı zamanda 'elif-nâme' formunda kaleme alınmıştır.

Bu çalışmamızda; Sükûtî Divanı'nda tespit ettiğimiz iki elif-nâmenin şekil ve muhteva incelemesi yapılacaktır. Ele alacağımız elif-nâmelerde dikkatimizi çeken bir başka husus da her iki elif-nâmenin aynı zamanda düvâz-nâme türünde yazılmış olmasıdır. Düvâz-nâme;"Şiilerin, Alevî-Bektaşîlerin Ali soyundan gelen On İki İmam için söyledikleri nefeslere verilen addır. Sadece düvâz-deh de denir.” (Artun,2014:167-168).

Bir tür olarak ilk düvâzların hangi şair-ozan tarafından söylendiği üzerinde çeşitli fikirler ortaya atılmıştır. Alevî-Bektaşî edebiyatında yaygın olarak yazılan ve bu inancın başta cemler olmak üzere birçok ritüelinde okunan düvâzların "Nesimî ve Sâdık Abdâl tarafından Şâh Hatayî'den daha önce yazıldığı tespit edilmiştir. Nesimî’nin divanındaki düvâzların XIV. yüzyıl sonları ile XV. yüzyılın başlarına tekabül ettiği görülmektedir. Nesimî, divanında düvâz geleneğine uygun olarak On İki İmam'ı sırasıyla zikretmektedir. Tür olarak düvâz-imamların en belirgin özelliği olan On İki İmam'ın sırasıyla zikredilmesi geleneğin başlangıcından itibaren bir form olduğu görülmektedir." (İyiyol,2013:232-233).

Düvâzlar ve düvâz-imamların; koşma, semai, gazel, murabba, müseddes, muhammes, terkib- i bend, terci-i bend ve kaside nazım şekilleriyle yazıldığı görülür. Murtazâ Sükûtî Divanı'nda 36 adet düvâznâme tespit edilmiştir. Bu sayı Rumeli'deki Sa'diyye tarikatında On İki İmam'a verilen değeri ve bu tarikatın Bektaşilikle ilgisini göstermesi açısından önem arz etmektedir. 


\section{Elif-nâme hakkında}

Edebiyatımızda şairler, zaman zaman harflerin ve kelimelerin hususiyetlerinden yararlanarak şiirlerinde hem estetik açıdan hem de şekil açısından farklı söyleyişler kullanmışlardır. Özellikle harfler "ilm-i hurûf denilen ayrı bir ilmin de konusu olmuştur. Bu ilimde harfler; sayıları, noktalı veya noktasız oluşları, biçimleri, mensubiyetleri, simge ve şifre değerleri, çıkış yerleri (mahrec), sesli veya sessiz oluşları, barındırdıkları ilâhî hikmet ve sırlar gibi yönlerden incelemeye tâbi tutulmuştur.” (Tökel, 2003:63). Farklı şekillerdeki bu şiirler araştırmacıların da dikkatini çekmiş ve bunlar üzerinde isimlendirmeler yapılmıştır.

Belagat ilmi içinde değerlendirilen şekil ile ilgili uygulamalar şairin tasarrufuyla edebi sanatsal bir ifadeye dönüşür.

"Bazen harflerin simgesel değerlerinden faydalanma bazen de harflerin yardimıyla kelime ve
kavramlar oluşturma gayesi güden bu farkh denemeler, çizgi dış olarak nitelendirebileceğimiz
uygulamalardır. Bu yüzden diğer edebî sanatlara göre edebiyatımzzda örneklerine az rastlanan bu
tür uygulamalar, belâgata dâhil edilen hünerler arasinda gösterilmiştir. Edebiyatımzzda; harflerin
cinslerine, birleşme veya okunuş şekillerine dayah bu tarz hünerlerden biri de muvaşşah olarak
adlandırılan ve daha çok görselliğe dayal olan yöntemdir." (Yekbaş, 2012:2649).

Elif-nâmelerin arketipi Zebur ve Yunan-Latin edebiyatına kadar götürülmektedir. (Memmedova, 2011:231) Türk edebiyatında elif-nâmeye ilk dikkat çeken araştırmacı Amil Çelebioğlu'dur. Harflerle ilgili yaptığı bir tasnifte elif-nâmelere yer veren Çelebioğlu, bu metinleri, divan ve halk edebiyatının ortak mahsullerinden kabul eder. Elif-nâmelerin dinî ve tasavvufî konular ağırlıklı olmak üzere her türden örnekleri olduğuna değinir(Çelebioğlu,1998:605). Yakın zamanda yapılan çalışmalara göre Türk edebiyatında tespit edilen ilk elif-nâme örneği XI. yüzyılda Burkan muhitinde 24 dörtlük olarak ortaya konulmuş olan ve sahibi belli olmayan bir şiirdir(Kaya, 2007: 309).

Elif-nâme ile ilgili araştırmacıların tarifleri şu şekildedir :

"Arap alfabesinin ilk harfi olan 'elif ile yazllmıs küçük kitap risale, varak anlamlarna gelen 'nâme' sözünün birleşmesinden meydana gelmiş birleşik isim olup, dîvan, âş̧k ve dinî tasavvufî Türk edebiyatlarında kullanılan bir türdür. Istılahî manası itibariyle de Osmanh Türkçesindeki otuz üç harfin değişik konularda, değişik şekillerle, genellikle mısra başlarındaki harflerin alt alta alfabetik sira ile beyitler halinde yazılarak devam etmesi neticesinde oluşan manzum eserlerdir (Güzel,2006:634).

Nihat Öztoprak, edebiyatımızdaki elif-nâmeleri genel olarak incelemiş, bu inceleme sonunda elif-nâme türünü şöyle tanımlamıştır:

"Elif-nâme, mısra veya beyitlerin ilk harfleri alt alta getirildiğinde elif'ten ye'ye alfabetik bir şekilde suralanan, ekseriyetle aruzun "fâ'ilâtün/ fâ'ilâtün/ fâ'ilâtün/ fẩilün" kahbryla ya da 11'li hece ölçüsüyle nazm edilen, gazel, kaside, müseddes gibi farkl şekillerle yazılabilen daha çok dinî ve didaktik konulu olmakla birlikte her konuda örnekleri görülebilen şïrlerdir.”(Öztoprak,2006:136) "Edebiyatımızda pek çok örneği bulunan elif-nâmeler, tertip hususiyetlerine göre beş gruba ayrlabilir: Birinci elif-nâme türü, mısra başlarındaki kelimelerin ilk harflerinin eliften ye'ye doğru alfabetik surayla yazılması şeklinde oluşan düz elif-nâmelerdir. Bu türde, genelde ilk kelimeden önce ilgili harf yazılır ve vezne dâhil edilir. Düz elif-nâmeler de kendi içinde mısra başları alfabetik olanlar, beyit ve dörtlük başları alfabetik olanlar, yalnızca mısra başında değil mısra içinde de harflerden biri ya da birkaçı yer alanlar, bir mısrasında baştaki harf ile başlayan en az iki veya daha fazla kelime kullamlanlar şeklinde gruplandirlabilir. İkinci elif-nâme türü, düz elifnâmelerin aksine mısra veya beyit başlarmın ye'den elif'e doğru siralanmasıyla meydana gelen ters elif-nâmelerdir. Üçüncü elif-nâmeler, mısra veya beyit başları elif-ye-be-lâmelif... şeklinde baştan sona ve sondan başa doğru karışık stralanan düz-ters elif-nâmelerdir. Dördüncü elifnâmeler, kafiyeleri alfabetik dizilen ve mesnevî nazım şekliyle yazılmış elif-nâmelerdir. Beşinci ve 
son elif-nâme türü ise eğitim amaçh olarak ve bir halk oyunu şeklinde tertip edilmiş olan elifnâmelerdir. Bu elif-nâmelerde mısra başlarındaki harfler, eliften ye'ye alfabetik olarak stralantrken ilk kelime bir şehir, ikinci kelime bir sanatkâr, üçüncü kelime ise o sanatkârın ortaya koyduğu eserin adıdır. Üstelik bu kelimelerin her biri, mısra başlarındaki harfle başlamak durumundadir." (Öztoprak 2007:818).

Bir başka tasnifte elif-nâmeler, "Şekil özellikleri bakımından mısra başında ve beyit halinde olanlar, mısra başında ve dörtlük halinde olanlar, mısra sonunda ve beyit halinde olanlar, mısra başında ve ortasında olanlar, destan tarzında yazılanlar şeklinde beş gruba ayrılmıştır. (Kaçar 1997: 310-313). Bu sınıflandırmaya "Ebced harfleri sıralamasına göre yazılmış olanlar da eklenebilir. Söz konusu şiirler alfabedeki sıralamaya göre değil, ebced harflerini oluşturan harf sırasına göre kurulmuştur." (Tökel 2010: 59-60).

Araştırmacıların, elif-nâmenin tür mü şekil mi olduğu konusunda farklı görüşleri vardır. Abdurrahman Güzel, elif-nâmeyi tür olarak nitelerken Nihat Öztoprak şekil olduğu yönünde tespitlerde bulunmuşlardır. İsmet Çetin bu farklılı̆̆ın sebebi olarak elif-nâmenin gazel, koşma, destan, divanî gibi hem şekil hem de tür özelliği gösteren şiirlerde uygulanmasını işaret eder (Çetin 1992: 40).

Yapılan gruplandırmalarda ve tanımlarda elif-nâmelerde muhtevadan çok şeklin ön plana çıktı̆̆ görülür. Alfabetik sıraya göre sıralama kuralı, şairi harfe göre kelime seçmeye sevk eder. İster mısranın ya da beyitin başında, ister ortasında, isterse sonunda olsun seçilen kelime mısranın genelinde kullanılacak kelimeleri, dolayısıyla cümleyi etkiler. Şair seçtiği kelimeyle anlamlı bir bütün oluşturacak kelimeler seçmek zorundadır. Böylece şekil kaygısı şiire anlam veren yapıyı yani şiirin dokusunu etkilemiş olur (Güvenç,2013:1005-1006).

Elif-nâmeler hem halk edebiyatı hem de klasik Türk edebiyatı şairleri tarafından tercih edilmiştir. Halk edebiyatında Dertli, Ruhsatî, Noksanî, Âşık Şenlik, Reyhânî, Âşık Zülalî, Seyranî, Kul Himmet, Âşık Ömer, Kaygusuz Abdal, Sefil Ali, Zahmî, Âşık Kenzi, Nihanî, Türabî, Ruhsatî’nin; klasik Türk edebiyatında Âşık Paşa, Nesîmî, Hatâyî, Muhibbî, Fuzûlî, Mihrî Hatun gibi önemli şairlerin elifname kaleme almış olmaları, divan şiirinde elif-nâmelere olan rağbeti göstermektedir. (Taşkesenlioğlu, 2017: 161) Elifname'nin coğrafyası Anadolu ile sınırlı değildir. Türk dünyasında yazılmış birçok elif-nâme vardır (Öztürk, 2012: 175). Osmanlı ve doğu edebiyatlarında sıklıkla görülen elifnamelere Orta Asya Türk edebiyatlarında da rastlanır (Gökçimen, 2010: 106). Son zamana kadar yapılan çalışmalarda elifnâmelerin tamamı manzum iken Kaygusuz Abdal'a ait olduğu tespit edilen bir elif-nâmenin diğerlerinin tersine mensur olduğu görülmüştür (Özkan, 2012: 187).Kaygusuz'un elif-nâmesi bu konu ile ilgili tartışmalara yeni bir madde daha eklemiştir. Sonraki dönemlerde tespit edilecek yeni elif-nâme metinleri arasında acaba kaçı mensur olarak karşımıza çıkacaktır. Bunu ancak zaman içinde ortaya çıkacak yeni metinler aydınlatacaktır.

\section{Murtazâ Sükûtî Divanı'ndaki Elif-nâmeler}

\section{3.a. Elif-nâme I}

Murtazâ Sükûtî Divanı'nın 2 no'lu şiiri olan birinci elif-nâme 'düz elif-nâme' olarak tertip edilmiştir. Şair, harflendirmeyi beyitlerin başında değil mısraların başında tercih etmiştir. Metin; Türk edebiyatında en çok tercih edilen vezinlerden fầilâtün fầilâtün fẩilâtün fẩilün vezniyle yazılmıştır. Elif-nâmenin nazım şekli gazeldir. Gazelin beyit sayısı 15’tir. 
Elif Allâh ism-i pâkiyle kelâmım ibtidâ

Be bize bürhân yeter nutk-ı Habîb-i Kibriyâ

Te teberrâ kıl Havâric kavmine her rûz u şeb

Se senâ et Murtazâ'ya cân u dilden tâlibâ

Cim cemâlin nûr-ı pâkinden bizi halk eyledi

Ha hayâtım sizden oldu yâ Hasan hulk-ı Rızâ

Hı haber verdi hakîkat râhını tâliblere

Dal delîl oldu bize hem şâh Hüseyn-i Kerbelâ

Zel zelîl et nefsini kibr ü nifâka düşmesin

Re riyâdan ictinâb et kılmasın Hak'dan cüdâ

Ze ziyâde kıl mahabbet Zeyne'l-Muhammed Bâkır'a

Sin sezâdır Ca'fer ile bunlara kıl iktidâ

Şın şarâb-ı kevseri Kâzım yedinden iç bugün

Sad safâ eyler derûnun ister isen zâhidâ

Dat dalâlet râhına verme gönül ey müddê̂

Ti tarîk-i müstakîmde bul Alî Mûsâ Rızâ

Zı zuhûr etdi bulardan küntü kenzin mahzeni

Men arefden ders oku gel sırrına ol âşinâ

Ayn aşk ile yakîn ol Mustafâ'nın âline

Gayn gayre bakmayıp hîç kıl Takî’ye ilticâ

Fe ferâgat eyle ey dil mâsivâdan çek elin

Kaf karîb ol sen Nakî̀ye bulmak istersen rehâ

Kef kerem-kânı Alî’nin nesli İmâm Askerî

Lam letâfet gösterir ol râh-ı aşkda sâlikâ

Mim Muhammed Mehdî’nin devrânına ol muntazır

Nun nihâyet buldu hüküm gelmege sâhib-livâ

Vav vücûdum mülkü içre zât-ı Hak etdi zuhûr

He hidâyet andan oldu bizlere her dâimâ

Lâmelif lâ demezem min külli eşyâ Hak'durur

Yâ yalanım yok Sükûtî gün gibi zâhir Hudâ

Elif-nâme, Türk edebiyatındaki klasik düvâz-nâme tertibine uygun kaleme alınmıştır. Elif harfi ile başlayan ilk mısrada Sükûtî, gazeline Allah'ın pak ism-i şerifini anarak giriş yapar. İkinci mısrada, 'Habîb-i Kibriyâ' sıfatıyla Hz. Peygamber'i yâd edilir:

Elif Allâh ism-i pâkiyle kelâmım ibtidâ

Be bize bürhân yeter nutk-ı Habîb-i Kibriyâ

İkinci beyitte Sükûtî, muhataplarını Hz. Ali'yi şehit eden Harici kavmine gece gündüz 'teberrâ' kılmaya davet eder. Alevi-Bektaşi kültüründe; "Âl-i Abâ'ya sevgi duymaya tevellâ, onlara karşı çıanları sevmemeye de teberrâ denir”(Cebecioğlu,2009:173). 
Te teberrâ kıl Havâric kavmine her rûz u şeb

Se senâ et Murtazâ’ya cân u dilden tâlibâ

Kronolojik olarak On iki İmam’ın isimleri şu şekildedir. Aşağıdaki isimlerin tamamı gazelde geçmiştir:

Hz. Ali, Hz. Hasan, Hz. Hüseyin, Zeyne'l-Âbidîn, İmam Bâkur, İmam Ca’fer, İmam Mûsâ-i Kâzım, İmam Rızâ, İmam Takî, İmam Nakî, İmam Askerî, İmam Mehdî.

Elif-nâmenin Zı harfi ile başlayan 9. beyitinde tasavvuf edebiyatımızda yaygın olarak kullanılan Men aref ve Küntü kenz hadislerine telmihte bulunulmuştur. İlk misradaki Küntü kenz ifadesi "Küntü kenzen mahfiyyen fe-ahbebtü en u'rafe fe-halaktü'l-halka hadisinden alınmıştır. Bu hadisin anlamı şöyledir: "Ben gizli bir hazine idim, bilinip tanınmay istedim ve bilinmek için mahlûkatı yarattım." Bu görüşe göre vücûd-ı mutlak olan Allah, aynı zamanda mutlak kemâl ve cemâle sahiptir. Mutlak güzellik ise, doğal olarak gizli kalmayıp görünmek, beğenilmek ve sevilmek ister(Üstüner, 2007: 73).Sükûtîye göre; Küntü kenz kudsî hadisinde gizli olan hazine yani yaratıcının sırları On İki İmam’da zuhur edip açı̆̆a çlkmıştır. Onlar, diğer insanlar içinde hususi bir yere sahiptir. Bu dünyada Allah'ın varlı̆̆ına ve birliğine işaret eden deliller en güzel şekilde On İki İmam ile temsil edilir.

İkinci beyitte geçen, men aref ifadesi "Men arefe nefsehü fekad arefe rabbuhü (kendini bilen Rabbini bilir)" kudsi hadisinden iktibastır. Şaire göre; On İki İmam'da tecelli eden sırra ermenin şartı ise kişinin men aref ten ders okumasına yani nefsinin hakikatini bilmesine bağlıdır.

Şair, aşağıdaki beyte kadar imamları sırasıyla yazmış, harfleri de yine sırasıyla her mısranın başında tercih etmiştir. Ancak kudsî hadislerin geçtiği bu beyitte, sadece beytin başında bir harf tercih ederek hem harflerin tertibinde farklı bir tercihte bulunmuş hem de diğer beyitlerde olduğu gibi herhangi bir isim yâd etmemiştir

Zi zuhûr etdi bulardan küntü kenzin mahzeni

Men arefden ders oku gel sırrına ol âşinâ

\section{3b. Elif-nâme II}

Divandaki diğer elif-nâme eserdeki 3 nolu manzumedir ve birinci elif-nâmeden hemen sonra gelmektedir. Bu elif-nâmede de tercih edilen nazım şekliyine gazeldir. Manzumenin beyit sayısı 16'dır. Metin; diğerinde olduğu gibi fầilâtün fẩilâtün fẩilâtün fầilün vezniyle yazılmıştır. Bu elif-nâme 'düzters elif-nâme’ olarak kaleme alınmıştır. Gazel, Türk edebiyatındaki klasik düvâz-nâme tertibine uygun kaleme alınmıştır.

Elif Allâh'a ederdim cân u dilden ilticâ

Ye yalanım levh-i dilden sür çıkarsın dâimâ

Be berâhîn-i kâtı ile Hâlık-ı kevneyn odur

Lâmelîf lâ demezem ben yok şerîkin mutlakâ

Te teberrâ kılmışız biz âl-i Mervân kavmine

He hidâyet bulmaz anlar cins-i har ehl-i cefâ

Se senâlar etmişim ben âl-i evlâda bugün

Ve vücûdum mülki içre şulesi urmuş ziyâ

Cim cemâl-i Mustafâ’ya tâ ezelden âşıkam 
Nun nikâbın açdı gördüm nûr ile dolmuş semâ

Hâ hayâtım Murtazâ'nın aşkiyla her rûz u şeb

Mim müzeyyen kıldı cismim hastegâna bir şifâ

Hı haberdâr olmuşuz biz Şâh Hasan esrârına

Lâ letâfet bulduk andan maden-i kenz-i hafâ

Dal delîlim Şâh Hüseyn-i Kerbelâ'dır şübhesiz

Kef kerâmet-kânı oldur mazhar-ı feyz-i Hudâ

Zel ziyâde kılmışım ben zât-ı pâkin hubbunu

Kaf karîbim tâ elestden hazret-i Zeyne'l-Abâ

Re risâlet cevheridir hazret-i Bâkır dahı

Fe fenâya ragbet etmez Hakk ile bulmuş bekâ

Ze ziyân ermez Cafer'den zâhidâ kıl inkıyâd

Gayn gayret-kânı oldur müşsülün eyler küşâ

Sin seherde zikrin etdim ol İmâm-ı Kâzım’ın

Ayn aşkı kalbim içre devr eder subh u mesâ

Şın şarâb-ı kevserinden bir kadeh nûş etmişim

Zı zuhûr etdi gönülde Şâh Alî Mûsâ Rızâ

Sad safâyım sâyesinde Şâh Takî’nin her dem

Ti tarîk-i müstakîmde bize oldu reh-nümâ

Dad dalâletden halâsım Şâh Nakî bürhân ile

Askerî’ye tâbi oldum nesl-i şâh-ı enbiyâ

Hâk-i pây-i Mehdî̀ye dervîş Sükûtî sür yüzün

Bâb-1 lutfun hâdimi ol hâcetin eyle revâ

\section{Elif-nâmelerin Karşılaştırılması}

\section{4.a. Harflerde Kullanılan Ortak Kelimeler}

\begin{tabular}{|l|l|}
\hline 1. Elif-nâme & 2. Elif-nâme \\
\hline Elif: Allah & Elif: Allah \\
\hline Be: Bürhan & Be: Berâhin \\
\hline Te: Teberrâ & Te: Teberrâ \\
\hline Se: Senâ & Se: Senâ \\
\hline Cim: Cemâl & Cim: Cemâl-i Mustafâ \\
\hline Ha: Hayât & Ha: Hayât \\
\hline Hı: Haber & Hı: Haberdâr \\
\hline Dal: Delîl & Dal: Delîl \\
\hline Zel: Ziyâde & Zel: Ziyâde \\
\hline Ze: Ziyân & Ze: Ziyâde \\
\hline Şın: Şarâb-ı Kevser & Şın: Şarâb-ı Kevser \\
\hline Sad: Safâ & Sad: Safâ \\
\hline
\end{tabular}




\begin{tabular}{|l|l|}
\hline Dat: Dalâlet & Dat: Dalâlet \\
\hline Tı: Tarîk-i müstakîm & Tı: Tarîk-i müstakîm \\
\hline Zı: Zuhûr & Zı: Zuhûr \\
\hline Ayn: Aşk & Ayn: Aşk \\
\hline Gayn: Gayr & Gayn: Gayret \\
\hline Kaf: Karîb & Kaf: Karîb \\
\hline Lam: Letâfet & Lam: Letâfet \\
\hline Vav: Vücûd & Vav: Vücûd \\
\hline He: Hidâyet & He: Hidâyet \\
\hline Lamelif: lâ demezem & Lamelif: lâ demezem \\
\hline Ye: yalan & Ye: yalan \\
\hline
\end{tabular}

\section{4.b. Harflerde kullanılan farklı kelimeler}

\begin{tabular}{|l|l|}
\hline Elif-nâme & 2. Elif-nâme \\
\hline Re: Riyâ & Re: Risâlet \\
\hline Sin: Sezâ & Sin: Seher \\
\hline Fe: Ferâgât & Fe: Fenâ \\
\hline Kef: Kerem-kân & Kef: Kerâmet-kân \\
\hline Mim: Müzeyyen & Mim: Muhammed \\
\hline Nun: Nihâyet & Nun: Nikâb \\
\hline
\end{tabular}

Yukarıdaki tablolarda görüldüğü gibi şair, her iki elif-nâmede 24 harfte kullandığı kelimeleri birebir aynı tercih etmiştir. Şiirlerde, Re, Sin, Fe, Kef, Mim ve Nun harfleri ile başlayan mısralarda farklı kelimeler kullanmıştır. Bu verilere göre Sükûtî, elif-nâmelerinde On İki İmam'la ilgili kalıp ifadeler seçmiş, seçtiği tasavvufî kavramları beyitlerde benzer şekilde kullanmıştır.

\section{4.c. Elif-nâmelerde On İki İmam'la ilgili sıfat ve benzetmeler}

\begin{tabular}{|l|l|l|}
\hline & Elif-nâme & Elif-nâme \\
\hline Hz. Muhammed & Habîb-i Kibriyâ & Mustafâ \\
\hline 1. Hz. Ali & Murtazâ, hastegâna şifa & Sen senâ et Murtazâ'ya \\
\hline 2. Hz. Hasan & Hayat sebebi & Ma'den-i kenz-i hafâ \\
\hline 3.Hz. Hüseyin & Şah Hüseyn-i Kerbelâ, delil & $\begin{array}{l}\text { Şah Hüseyn-i Kerbelâ, kerâmet-kânı, mazhar-1 } \\
\text { feyz-i Hudâ }\end{array}$ \\
\hline 4.Zeyne'l-Âbidîn & Muhabbet kıl & Zeyne'l-Abâ, elestden beri ruha yakın olan \\
\hline 5.İmam Bâkır & Muhabbet kıl & Risâlet cevheri \\
\hline 6.İmam Ca'fer & Muhabbet kıl & Gayret kânı, müşkül-küşa \\
\hline 7.İmamM. Kâzım & Elinden Şarâb-1 Kevser nuş edilen & Aşkı kalp içre subh u mesa devr eden \\
\hline 8.İmam Rızâ & Tarik-i müstakimde bulunan & Şarab-ı kevserinden nuş edilen \\
\hline 9.İmam Takî & İltica kılınan & Tarik-i müstakimde reh-nümâ \\
\hline 10.İmam Nakî & Reha bulmak için yakîn olunan & Dalaletden halas eden \\
\hline
\end{tabular}




\begin{tabular}{|l|l|l|}
\hline 11.İmam Askerî & Keramet kânı & Nesl-i şah-ı enbiya \\
\hline 12.İmam Mehdî & Zamanı beklenen & Hak-i payine yüz sürülen \\
\hline
\end{tabular}

Murtazâ Sükûtî’nin elif-nâmeleri , elif-nâme geleneğinde yaygın olarak kullanılan düvâz-nâme türünde kaleme alınmıştır. Türk edebiyatının büyük şairi Fuzûlînnin divanındaki 'Der Medh-i Hazret-i Şâh-ı Velâyet ve Sitâyiş-i E'imme-i İsnâ Aşer' (Parlatır, 2014: 66-68) başlıklı mazume de elif-nâmenin tercih edildiği bir düvâz-nâmedir. Fuzûlî dışında Hatâyî (Özcan, 2015: 200-201), Kıbrıslı Kenzî (Batislam, 2018: 7-16) gibi pek çok şairin düvâz-nâme olarak yazılan elif-nâmeleri vardır. Sükûtînnin elif-nâmeleri, hem düvaz-nâme hem de elif-nâmeler ile ilgili yapılan akademik çalışmalara katkı sağlayacaktır.

\section{Sonuç}

Balkan coğrafyasında yetişen Şeyh Murtazâ Sükûtî, bu topraklarda küçümsenmeyecek bir kitle tarafından gören Sa'diyye tarikatının felsefesini şiirlerinde yansıtmış, bununla muhataplarını irşâd etmeyi amaçlamıştır. Balkan coğrafyasının tamamını etkileyen Alevî-Bektaşî kültürü, bu topraklarda gelişen her tarikat gibi Sa'diyye tarikatını da derinden etkilemiştir. Sükûtî Divanı'nda bu etkileşim ile ilgili sayısız örnek bulunmaktadır. Şair, divanında baştan sona Hz.Ali'ye, Ehl-i Beyt'e ve On İki İmam'a olan sevgisini veciz bir üslupla kaleme almıştır. Öyle ki; bu muhabbetin ifade edildiği şiirler diğer manzumelere göre daha başarılıdır. Alevî-Bektaşî bir şair Hz. Ali ve Ehl-i Beyt sevgisini ne kadar işlemiş ise Şeyh Murtazâ Sükûtî de o kadar işlemiştir.

Çalışmamızda ele aldığımız elif-nâme şeklinde yazılan iki şiirde de Murtazâ Sükûtî’nin Ehl-i Beyt sevgisi açıç̧a görülmektedir. Elif-nâmelerin On İki İmam’ı konu edinmesi Düvâz- imam türünde yazılması Ehli Beyt sevgisi bağlamında dikkate değer bir özelliktir.

Edebiyatımızda herkes tarafindan tercih edilmeyen elif-nâme formunu kullanan Sükûtî, elif-nâme olarak kaleme aldığı düvâz-nâmelerinde okuyucunun dikkatini -başta Ehl-i Beyt olmak üzere- On İki İmam muhabbetine yönlendirmek istemiş olabilir.

Murtazâ Sükûtî Divanı'nda 36 adet düvâz-nâme tespit edilmiştir. Elde edilen sonuca göre divanda, düvâz-nâme türü en fazla tercih edilen türdür. Bu sayı Rumeli'deki Sa'diyye tarikatında On İki İmam'a verilen değeri ve bu tarikatın Bektaşilikle ilgisini göstermesi açısından önem arz etmektedir.

Murtazâ Sükûtî’nin, elif-nâme formunda ve düvâz-nâme türünde yazdığı bu şiirler, edebiyatımızda birçok şairimiz tarafından kaleme alınan düvâz-nâmeler ve hala üzerinde tartışlan elif-nâmeler hakkında yapılacak genel çalışmalara ışık tutacaktır.

\section{Kaynakça}

Artun, Erman (2014). Ansiklopedik Halkbilimi/Halk Edebiyatı Sözlüğü, Terimler-Motifler-Kavramlar, Karahan Kitabevi, Adana.

Batislam, Dilek (2018). "Kıbrıslı Âşık Kenzînnin Elif-Nâmeleri”, Kıbrıs Araştırmaları ve İncelemeleri Dergisi, Lefkoşa, C.1,S.2,ss-7-16)

Cebecioğlu, Ethem (2009). Tasavvuf Terimleri ve Deyimleri Sözlüğü, Ağaç Kitabevi, İstanbul.

Çelebioğlu, Amil (1998). Eski Türk Edebiyatı Araştırmaları, MEB Yayınları, Ankara.

Güzel, Abdurrahman (2006). Dinî-Tasavvufî Türk Edebiyatı, Akçağ Yayınları, III. Baskı, Ankara.

Gökçimen, Ahmed (2010). “Türkmen Edebiyatında Elif-name”, A.Ü. Türkiyat Araştırmaları Enstitüsü Dergisi, Erzurum,S.43, ss.105-120. 
İyiyol, Fatih (2013). "Alevî Bektaşî Geleneğinde Düvâzlar-Düvâzimamlar” Uluslararası Sosyal Araştırmalar Dergisi, C.6 S. 27,ss.228-250.

Kaçar, Burhan, (1997). “Türk Edebiyatında Elif-Nâmeler”,V. Milletlerarası Türk Halk Kültürü Kongresi Seksiyon Bildirileri I, Kültür Bakanlığı Yayınları, Ankara ss. 307-316.

Kaya, Doğan (2007). Ansiklopedik Halk Edebiyatı Terimleri Sözlüğü, Akçă̆ Yayınları, Ankara.

Kiel, Machiel (2016). “Köprülü ” İslam Ansiklopedisi, Türkiye Diyanet Vakfı Yayınları, İstanbul, C.Ek-2.

MemmedovA, Elmira Memmedova (2011). “Türk Tasavvuf Şiirinde Elifnâme-Yaşnâmenin Senkretik Bir Örneği Üzerine”, 21.Yüzyılda Türk Dünyası Uluslararası Sempozyumu Bildirileri, Eko Avrasya Yayınları,Lefke KKTC, ss.231-243.

Özcan, Hüseyin (2015). “Hatâ̂’nin Elifnâme Şeklinde Yazdı̆̆ı Düvazdeh”, Türk Kültürü ve Hacı Bektaş Velî Araştırma Dergisi, S.76,ss. 191-204.

Özcan, Nurgül (2011). Murtazâ Sükûtî Dîvânı, Kitapsal Yayın, İstanbul.

Özdamar, Mustafa (1997). Şeyh Sükûtî Murtazâ Baba, Özdamar Yayınları, İstanbul.

Özkan, Ferudun Hakan (2012). "Kaygusuz Abdal'ın Elifnâmesi”, Türk Kültürü ve Hacı Bektaş Velî Araştırma Dergisi, S. 64, ss. 187.

Öztoprak, Nihat (2006). "Bursalı Feyzi Efendi'nin Elif-nâmeleri”, İstanbul Üniversitesi Edebiyat Fakültesi Türk Dili ve Edebiyatı Dergisi, C. XXXV, ss. 135-167.

Öztoprak, Nihat (2007). "Elif-nâmelerin Tertip Hususiyetleri ve Metin Tesisindeki Yeri” Uluslararası Türklük Bilgisi Sempozyumu Bildiriler-2, ss.817-830.

Öztürk, Nuran (2012). "Elifnâme ve Nidâi’nin Elifnâmesi”, Prof. Dr. Mine Mengi adına Türkoloji Sempozyumu (20-22 ekim 2011), Bildiriler, Adana, ss.175.

Parlatır, İsmail (2014). Fuzuli -Türkçe Divan, Akçağ Yayınları,Ankara

Üstüner, Kaplan (2007). Divan Şiirinde Tasavvuf (14. ve 15. yy. Divanlarına Göre), Birleşik Yayınları, Ankara.

Taşkesenlioğlu, Lokman (2017). "Divan Edebiyatında Elifnameler ve Bilinmeyen İki Elifname Örneği: Memi Can Saruhânî Ve Ömer Karîbî Elifnameleri”, Türkiyat Araştırmaları Enstitüsü Dergisi [TAED], S.58, Erzurum, 2017, ss. 161.

Tökel, Dursun Ali (2010). Deneysel Edebiyat Yönüyle Divan Şiiri, Hece Yayınları, Ankara.

Tökel, Dursun Ali (2003). Divan Şiirinde Harf Simgeciliği, Hece Yayınları, Ankara.

Yekbaş, Hakan (2012). "Divan Şairinin Sessiz ve Gizli Anlatımı: Muvaşşah” Turkish Studies Dergisi, S.7/3,ss.2649-2700. 